\title{
Sosyal Bilgiler Öğretim Programı Ve 4-7. Sınıf Sosyal Bilgiler Ders Kitaplarının Coğrafya Kavramları Bağlamında Değerlendirilmesi ${ }^{1}$
}

\author{
Turan KAÇAR \\ Dr., Öğretmen, Milli Ĕgitim Bakanlı̆̆ \\ Gazi Orta Okulu/Diyarbakır \\ kacarturan21@gmail.com \\ Orcid ID: https://orcid.org/0000-0001-8390-7262
}

\author{
Birol BULUT \\ Doç. Dr., Fırat Üniversitesi, \\ Eğitim Fakültesi, Türkçe ve Sosyal Bilimler Eğitimi Bölümü \\ birolbulut1@gmail.com \\ Orcid ID: https://orcid.org/0000-0002-3116-7087
}

\section{Öz}

Bu çalışmanın amacı 2018 Sosyal Bilgiler Öğretim Programını (SBÖP) ve 2019-2020 eğitim-öğretim yılında Türkiye'de 4-7. sinıflarda okutulan sosyal bilgiler ders kitaplarını coğrafya kavramları bağlamında, çeşitli değişkenler açısından değerlendirmektir. Bu çalışma, nitel bir araştırma olup bu çalışmada nitel araştırmalarda uygulanan doküman analizi tekniği kullanılmıştır. $\mathrm{Bu}$ çalışmada, doküman olarak 2018 SBÖP ve Milli Eğitim Bakanlığının ülkemizde 2019-2020 eğitim-öğretim yılında okuttuğu 4-7. sınıf sosyal bilgiler ders kitapları incelenmiştir. $\mathrm{Bu}$ çalışma verilerinin analizinde betimsel analiz tekniği kullanılmıştır. Bu çalışmanın sonuçlarına göre; SBÖP'de yer alan 27 beceriden sadece dördü coğrafya kavramları ile doğrudan ilişkilidir. SBÖP'de yedi öğrenme alanı ve 131 kazanım vardır. SBÖP'de yer alan yedi öğrenme alanından sadece İnsanlar, Yerler ve Çevreler coğrafya kavramları ile bütünüyle ilgiliyken Üretim, Dağıtım ve Tüketim ve Küresel Bağlantılar öğrenme alanları ise kısmen coğrafya kavramları ile ilgilidir. SBÖP'de 4-7. sınıf düzeyindeki öğrenme alanlarında coğrafya kavramları bağlamında yer alan tüm kazanımların oranı \%29,7 iken ders saati oranı ise \%30,5'tir. 2019-2020 eğitim-öğretim y1lında okutulan 4-7. sınıf sosyal bilgiler ders kitapları incelendiğinde sadece 7. sinıf sosyal bilgiler ders kitabındaki öğrenme alanlarında öğrenci öz değerlendirme formlarına yer verilmiştir. Bu sonuçlar doğrultusunda coğrafya kavramlarının sosyal bilgiler

\footnotetext{
${ }^{1}$ Makale Geliş/Kabul Tarihi: 17.05.2020 / 30.09.2020

Künye Bilgisi: Kaçar, T. ve Bulut, B. (2020). Sosyal Bilgiler Öğretim Programı ve 4-7. Sinif Sosyal Bilgiler Ders Kitaplarının Coğrafya Kavramları Bağlamında Değerlendirilmesi. Kahramanmaraş Sütçü İmam Üniversitesi Sosyal Bilimler Dergisi, 17 (2), 652-679. DOI: 10.33437/ksusbd.738637
} 
dersinde önemli bir oranda yer alması öğrencilerin bilişsel ve sosyal gelişimine katkı sağlayacağı söylenebilir.

Anahtar Kelimeler: Sosyal Bilgiler, Sosyal Bilgiler Öğretim Programı, Coğrafya, 4-7. Sınıf Sosyal Bilgiler Ders Kitapları.

\title{
Evaluation of the Social Studies Curriculum and 4-7th Grade Social Studies Testbooks in the Context of the Geography Concepts
}

\begin{abstract}
The aim of this study was 2018 Social Studies Curriculum (SSC) and the 2019-2020 academic year in social studies textbooks taught in 4-7th grade in Turkey in the context of geography concepts, evaluate the different variables. This study is a qualitative research and document analysis technique applied in qualitative research was used in this study. In this study, 4-7th grade social studies textbooks taught by the Ministry of National Education in the 2019-2020 academic year and 2018 SSC were examined as a document. The descriptive analysis technique was used in the analysis of the data of this study. According to the results of this study; Only four of the 27 skills in the SSC are directly related to geography concepts. There are seven learning areas and 131 learning outcomes in SSC. Among the seven learning areas in the SSC, only People, Places and Environments are entirely related to the concepts of geography, while the production, distribution and consumption and Global Connections learning areas are partially related to the concepts of geography. The rate of all learning outcomes in the 4-7th grade learning areas within the context of geography concepts in SSC is $29.7 \%$, while the lecture hour rate is $30.5 \%$. When the $4-7$ th grade social studies textbooks taught in the 2019-2020 academic year were examined, only the 7th grade social studies textbook included student selfassessment forms in the learning areas. In line with these results, it can be said that the important part of geography concepts in social studies course will contribute to the cognitive and social development of the students.
\end{abstract}

Keywords: Social Studies, Social Studies Curriculum, Geography, 4-7th Grade Social Studies Textbooks. 


\section{GİRIŞ}

Sosyal bilgiler eğitiminde farklı yaklaşımların bütüncül bir bakış açısıyla yer aldığı bilinmektedir. Dewey, öğretim ortamlarında sosyal bilgiler öğretimi uygulamaları gerçekleştirerek sosyal bilgiler eğitimi alanında yeni yaklaşımların ortaya çıkmasını sağlamıştır (Yeşiltaş ve Kaymakçı, 2009). Bu bağlamda sosyal bilgiler kavramı her şeyden önce bir ders programını ifade ettiği söylenebilir. Bu programın hedeflerine ulaşmasında coğrafi kavramların, becerilerin doğru ve yeterince kazanılması gerekmektedir. Nitekim sosyal bilgiler dersinin sosyal bilimler alanında yer alan çeşitli disiplinlerden oluşmasından dolayı sosyal bilgiler eğitimine dair çeşitli yaklaşımlar birçok sosyal bilgiler tanımının meydana gelmesini sağlamıştır (Öztürk ve Otluoğlu, 2003). Bu tanımlar incelendiğinde; Öztürk (2015) sosyal bilgileri, gelişen dünyada aktif bir biçimde problem çözen ve karar veren bireylerin yetiştirilmesi için sosyal ve beşeri bilimlerden aldığı bilgi ve yöntemleri bütünleştirerek uygulayan bir öğretim programı; Sönmez (2010) ise toplumsal gerçeklerle kanıtlanmaya dayalı ilişkiler kurma süreci ve bu sürecin sonunda elde edilen dirik bilgiler olarak tanımlamıştır. Sosyal bilgiler dersinin birçok branşa ait konuyu bünyesinde barındırması birçok farklı bakış açısını üzerine çekmekte ayrıca bireylerin çevreye yönelik bütün davranışlarının etkisinin çocuklara ve dünyanın farklı bölgelerinde yaşayan insanlara yansıdığının farkında olmalarında, doğaya saygılı olmalarında ve bu hususta motive edilmelerinde sosyal bilgiler eğitiminin önemli görevleri vardır (Kaya ve Tomal, 2011). Elbette ki bu tanımları ve açıklamaları artırmak mümkündür ancak özetle sosyal bilgiler; Sosyal bilimler alanında yer alan disiplinlerin bütünleştirilerek uygulandığg ve 4-7. sınıflar arasında uygulanan bir ders olarak tanımlamak yeterlidir.

$\mathrm{Bu}$ açıklamalar doğrultusunda sosyal bilgilerin tanımının yapılmasının yanı sıra ayrıca öğretim programının tanımını da yapmak gerekir. Örneğin Demirel (2013) öğretim programını, herhangi bir eğitim basamağında derslerde işlenecek konularla ilgili tüm etkinlikleri kapsayan bir süreç; Çakmak, Kaçar ve Arıkan (2019) ise ders kitaplarının ve ders içeriklerinin hazırlanmasında veya bir dersin planlanmasında, eğitim yaşantılarının düzenlenmesinde ve öğrencilerin değerlendirilmesinde bir rehber görevi üstlenen bir program olarak tanımlamaktadır. Demirel (2013) ve Akpunar (2010) ise öğretim programını "okulda ya da okul dışında bireye kazandırılması planlanan bir dersin öğretimiyle ilgili tüm etkinlikleri kapsayan yaşantılar düzeneği” olarak tanımlamıştır.

$\mathrm{Bu}$ doğrultuda öğretim programının tanımı açıklandıktan sonra ayrıca sosyal bilgiler öğretim programını da tanımlamak önemlidir. Nitekim Sosyal Bilgiler Öğretim Programı (SBÖP), gelişen dünyada aktif bir biçimde problem çözen, karar veren bireylerin yetiştirilmesi için beşeri ve sosyal bilimlerden aldığ 1 yöntemleri ve bilgileri bütünleştirerek uygulayan bir öğretim programıdır 
(Öztürk, 2015). SBÖP, Türkiye'de aktif ve demokratik vatandaşlar yetiştirmek amacıyla, evrensel değişimleri de göz önünde bulundurarak belli aralıklarla ilgili kurumlar tarafından değiştirilen ve ilgili kurumlar tarafından gerçekleştirilen bu değişiklikler bazen düzenleme bazen de tamamen ortadan kaldırıp yeni bir özellik ilave etme biçiminde günümüze kadar gelmiştir (Koçoğlu ve Aydın, 2018).

$\mathrm{Bu}$ bağlamda dünyamızda inanılmaz bir biçimde değişim yaşanmakta; değişen sınırlar, savaşlar, göçler, teknoloji, küresel organizasyonlar yurttaşlık anlayışında da değişimi zorunlu kılmıştır ve toplumsal yapıdaki bu değişimler öğretim programlarını etkilemiş̧ir (Güven, 2011). Beşeri alandaki karmaşık problemlere çözüm arayışı SBÖP'nin farklı anlayışlarla yeniden şekillenmesine neden olmuş ve bu doğrultuda öğretim programlarında değişiklikler yapan ülkeler 2000'li yıllardan sonra yeni ya da revize edilmiş öğretim programlarını hayata geçirmiştir (Özdemir Özden, 2016). Aykaç (2007) da bireyin gelişiminde, topluma uyumlu, üretken ve verimli bireyler olarak yetişmesinde tartış1lamayacak kadar önemli bir konuma sahip olan SBÖP'nin bilim ve teknolojideki değişmeler, sosyokültürel dönüşümler, toplumsal, siyasal, ekonomik evirilmeler, bireyin ve toplumun gereksinimleri dikkate alınarak bilimsel bir yaklaşımla sürekli bir biçimde geliştirilmesinin bir zorunluluk olduğunu ifade etmiştir. Tüm bu açıklamalara ilaveten Milli Eğitim Bakanlığ 1 (MEB, 2018) da, öğretim programlarının bireysel, toplumsal, ekonomik ve bilimsel alanlarda yaşanmakta olan değişim ve gelişime paralel olarak belirli periyotlarda yenilendiğini açıklamıştır. Bu açıklamalardan hareketle öğretim programlarının içeriğinin sürekli gözden geçirilmesi, değerlendirilmesi ve güncellenmesinin eğitim ve öğretim açısından oldukça olumlu olduğu ifade edilebilir.

$\mathrm{Bu}$ açıdan öğretim programlarının en önemli özelliğinin değişen dünya koşullarına bağlı olarak güncellenmesi veya değişikliğe uğraması gerektiği söylenebilir. Bu açıklamadan hareketle ülkemizde 2005-2006 eğitim-öğretim yılından beri 4-7. sınıfları kapsayan SBÖP'nin yeni bir yaklaşımla (Yapılandırmacılık) amaçlarında, öğretim süreçlerinde ve değerlendirme biçimlerinde önemli ölçüde değişiklikler yapılmıştır (Özdemir, 2014). Benzer şekilde Ambarlı (2010), Yeşilyurt (2011), Aydın (2016) ve Çakmak, Kaçar ve Arıkan (2017) da 2005-2006 eğitim-öğretim yılından itibaren ülkemizde yapılandırmacı yaklaşıma uygun olarak hazırlanan öğretim programlarının uygulandığını belirtmiştir. Nitekim MEB (2018) de ülkemizde 2017-2018 eğitimöğretim yılında uygulanan öğretim programlarında yapılandırmacı yaklaşımın dikkate alındığı ifade edilmişsir. Bu açılamalardan hareketle yapılandırmacı öğrenme yaklaşımını da tanımlamak ve açıklamak gerekir.

$\mathrm{Bu}$ açıklamalar doğrultusunda yapılandırmacılık kısaca, öğretim programlarında benimsenen ve daha çok öğrencilerin merkeze alındığı bir 
öğrenme yaklaşımı olarak tanımlanabilir. Nitekim yapılandırmacı yaklaşım, öğretim programlarında önemli değişikliklere yol açarak öğrencilere ve öğretmenlere yüklenen görevleri ve rolleri değiştirmiştir (Dinç ve Doğan, 2010). Öğretim programlarında yer alan yapılandırmacı yaklaşımla öğrencinin bilgiye doğrudan ulaşması yerine öğretmenlerin rehberliğinde bilgiyi öğrencilerin keşfetmesi amaçlanmıştır ve bu doğrultuda bu yaklaşım öğretmenler ve ögrenciler için bir rehber ve yol göstericidir (Ambarl1, 2010). Bunun yanında Dinç ve Doğan'a (2010) göre yapılandırmacı yaklaşımın etkin bir biçimde uygulanabilmesi bu yeni rollerin teorik olarak öğrenilmesinden çok gerçek eğitim durumlarına nasıl aktarılacağına bağlıdır.

$\mathrm{Bu}$ çalışma kapsamında coğrafya kavramları doğrultusunda SBÖP'nin amaçlarını belirlemek de ayrıca önemlidir. Bu doğrultuda SBÖP incelendiğinde MEB'in (2018) SBÖP'de coğrafya kavramları bağlamında öğrencilerden ulaşılması beklenen özel amaçları şunlardır: "Yaşanılan çevre ile dünyanın genel coğrafi özelliklerini tanıma, insan ve çevre arasındaki etkileşimi açıklama, mekânı algılama becerilerini geliştirme, doğal çevrenin ve kaynakların sınırlılı̆̆ının farkına varıp çevre duyarlılığ içerisinde doğal kaynakları korumaya çalışma ve sürdürülebilir bir çevre anlayışına sahip olma". Bu amaçların gerçekleştirilmesinde ve SBÖP'nin uygulanmasında coğrafya kavramları bağlamında ayrıca aşağıdaki hususlara da dikkat edilmesi gerektiği düşünülmektedir: "Konular disiplinler arası bir yaklaşımla ele alınmalı" ve SBÖP kazanımlarının gerçekleştirilmesinde "yerellik, güncellik, disiplinler arası, yansıtıcı sorgulama, geçmiş bugün-gelecek bağlantısı, zaman-süreklilik-değişim ve esneklik" gibi sosyal bilgiler ögretiminin temel ilkeleri dikkate alınmalıdır (MEB, 2018).

Bu açıklamaların dışında SBÖP'de önemli olan bir diğer husus ise MEB'in (2018) Türkiye Yeterlilikler Çerçevesinde (TYÇ) belirlediği yetkinlikler kavramıdır. "Eğitim sistemimiz yetkinliklerde bütünleşmiş bilgi, beceri ve davranışlara sahip karakterde bireyler yetiştirmeyi amaçlar. Öğrencilerin hem ulusal hem de uluslararası düzeyde; kişisel, sosyal, akademik ve iş hayatlarında ihtiyaç duyacakları beceri yelpazeleri olan yetkinlikler Türkiye Yeterlilikler Çerçevesinde belirlenmiştir” (MEB, 2018). Eğitim-öğretim programlarıyla sürdürülen tüm çalışmaların amacı; Okul öncesinden ortaöğretime kadar birbirini tamamlayıcı bir şekilde öğrencilerin kazandıkları yetkinlikleri geliştirmek suretiyle millî ve manevi değerleri benimsemeleri, haklarını kullanmalarını ve sorumluluklarını yerine getirmelerini sağlamaktır (MEB, 2018). Bu açılamalardan hareketle SBÖP'de bulunan ve TYÇ'de yer alan sekiz anahtar yetkinlik Tablo 1'de verilmiştir. 
T. Kaçar-B. Bulut $\quad$ Sosyal Bilgiler Öğretim Programı ve 4-7. Sınıf...

Tablo 1. TYÇ’de Yer Alan Yetkinlikler

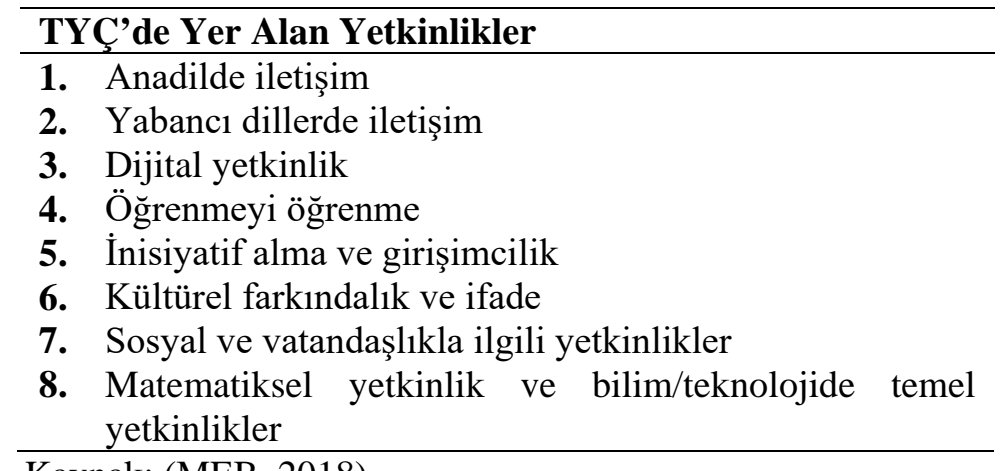

Kaynak: (MEB, 2018)

Tablo 1 incelendiğinde TYÇ' de yer alan yetkinliklerden "inisiyatif alma ve girişimcilik, kültürel farkındalık ve ifade ve sosyal ve vatandaşlıkla ilgili yetkinlikler"in daha çok sosyal bilgiler dersi ile doğrudan ilişkilendirilebileceği söylenebilir. Bu bağlamda kültürel farkındalık ve sosyal yetkinlikler coğrafya kavramları ile kısmen ilişkilendirilebilir. Nitekim kültür ve sosyal yetkinlikler coğrafya kavramları arasında yer almaktadır. TYÇ kapsamında yer alan diğer yetkinliklerin ise tüm disiplinler bağlamında bütünleşik bir şekilde öğrencilere kazandırılabileceği düşünülmektedir.

Tüm bu açıklamalar 1şığında bir öğretim programı ne kadar iyi hazırlanırsa hazırlansın, programın uygulanması doğrultusunda gerekli koşullar sağlanmamışsa programın başarılı olması da o ölçüde azalacaktır ayrıca SBÖP, öğretmenlerden gerekli desteği bulamaması durumunda uygulamada güçlükler oluşturabilir ve bunlar da öğrencilerin derse yönelik tutumlarını etkileyebilir (Çelikkaya ve Kürümlüoğlu, 2018). Bu açıklamalardan hareketle SBÖP’nin uygulanmasında ve ders kitaplarının okutulmasında eğitim ve öğretimin en önemli unsurlarından biri olana öğretmenlere önemli görevlerin düştüğü söylenebilir.

Tüm bu açıklamalar doğrultusunda bu çalışmanın ana problemi 2018 SBÖP ve 2019-2020 eğitim-öğretim y1lında 4-7. sınıflarda okutulan sosyal bilgiler ders kitaplarının coğrafya kavramları bağlamındaki düzeyini belirlemektir. $\mathrm{Bu}$ doğrultuda bu çalışmanın amacı SBÖP'yi ve 2019-2020 eğitim-öğretim yılında 4-7. sinıflarda okutulan sosyal bilgiler ders kitabını coğrafya kavramları bağlamında değerlendirmektir. Bu çalışma kapsamında bu amaçlara yönelik olarak aşağıdaki sorulara yanıtlar aranmıştır:

1. SBÖP'de yer alan coğrafya kavramları bağlamındaki beceriler nelerdir?

2. SBÖP'de yer alan öğrenme alanlarının ilgili oldukları alanlar nelerdir? 
3. SBÖP'de yer alan coğrafya kavramları ile ilişkili olan öğrenme alanlarındaki kazanımların ve ders saatinin dağılımı ne düzeydedir?

4. 2019-2020 eğitim-öğretim yılında ülkemizde okutulan 4-7. sınıf sosyal bilgiler ders kitabının öğrenme alanlarında coğrafya kavramları kapsamında yer alan konular nelerdir?

5. 2019-2020 eğitim-öğretim yılında ülkemizde okutulan 4-7. sınıf sosyal bilgiler ders kitaplarının öğrenme alanlarında coğrafya kavramları bağlamında yer alan konuların edebi ürün, soru, etkinlik, görsellik ve ölçme-değerlendirme boyutu ne düzeydedir?

Bu çalışmayla, SBÖP ve 4-7. sınıf sosyal bilgiler ders kitapları coğrafya kavramları bağlamında bütüncül bir bakış açısıyla incelenerek değerlendirilmiştir. Bu çalışma SBÖP, sosyal bilgiler ve coğrafya eğitimine kaynak olması açısından oldukça önemlidir. Bu çalışma, SBÖP'nin ve 4-7. sınıf sosyal bilgiler ders kitaplarının coğrafya kavramları bağlamında eksik kalan yönlerinin tespit edilmesi açısından da oldukça önem arz etmektedir ayrıca yapılan literatür taramasında SBÖP'nin ve 4-7. sinıf sosyal bilgiler ders

kitaplarının coğrafya kavramları bağlamında incelenmesine ve değerlendirilmesine yönelik herhangi bir çalışmaya rastlanılmaması da bu çalışmanın özgünlüğünü ve bu çalışmaya duyulan ihtiyacı göstermektedir.

\section{YÖNTEM}

Bu bölümde araştırmanın modeline, kapsamına veri toplama aracına, verilerin toplanmasına ve verilerin analizine yönelik bilgilere yer verilmiştir.

\section{Araştırmanın Modeli ve Kapsamı}

$\mathrm{Bu}$ çalışmada, nitel araştırma yöntemlerinden olan doküman incelemesi tekniği uygulanmıştır. Yıldırım ve Şimşek (2013) doküman incelemesi tekniğini kısaca araştırılması hedeflenen olgular ile ilgili bilgileri içeren yazılı materyallerin analizini kapsayan bir teknik olarak tanımlamıştır. Bu çalışma kapsamında, doküman olarak 2018 SBÖP ve MEB'in ülkemizde 2019-2020 eğitim-öğretim yılında 4-7. sinıflarda okuttuğu sosyal bilgiler ders kitapları incelenmiştir.

\section{Veri Toplama Aracı ve Verilerin Toplanması}

$\mathrm{Bu}$ çalışmada araştırmacılar, SBÖP ve 4-7. sınıf sosyal bilgiler ders kitaplarının coğrafya kavramları bağlamında çeşitli değişkenler açısından incelenmesine yönelik bir değerlendirme formu geliştirmiş̧ir. Daha sonra iki araştırmacı bu formu ayrı ayrı doldurarak SBÖP'yi ve 4-7. sınıf sosyal bilgiler 
ders kitaplarını coğrafya kavramları bağlamında incelemiştir. Bu bağlamda değerlendirme formlarından toplanan veriler tablolara aktarılarak yorumlanmıştır.

\section{Verilerin Analizi}

$\mathrm{Bu}$ çalışmada, verilerin analizinde betimsel analiz tekniği kullanılmıştır. Yıldırım ve Şimşek'e (2008) göre betimsel analiz ile elde edilen bulgular düzenlenmiş ve yorumlanmış bir biçimde okuyucuya sunulur. Yine Yıldırım ve Şimşek'e (2013) göre betimsel analizin; analiz için bir çerçeve oluşturma, belirlenen çerçeveye göre verilerin işlenmesi, bulguların tanımlanması ve bulguların yorumlanması gibi dört aşaması vardır.

$\mathrm{Bu}$ çalışma kapsamında toplanan veriler iki araştırmacı tarafından ayrı olarak kodlanmıştır böylece Miles ve Huberman'ın (1994) ifade ettiği kodlayıcı güvenirliği sağlanmıştır. Araştırmacıların ayrı ayrı kodladığı bu veriler Miles ve Huberman'ın (2016) belirlediği "Görüş birliği sayısı / toplam görüş birliği + görüş ayrılığı sayısı" formül uygulanarak bu çalışmanın güvenirliği hesaplanmıştır. $\mathrm{Bu}$ doğrultuda belirlenen formülün uygulanması sonucunda bu çalışmanın güvenirlik oranı $\% 85$ olarak tespit edilmiştir. Miles ve Huberman'a (1994) göre bu tip nitel çalışmalarda güvenirliğin \%70'in üzerinde olması güvenirlik için uygun ve yeterlidir.

\section{BULGULAR}

Bu bölümde SBÖP'de yer alan becerilere, öğrenme alanlarına, öğrenme alanlarının ilgili olduğu alanlara, 4-7. sınıf sosyal bilgiler dersinde yer alan coğrafya kavramları bağlamındaki kazanımlara, ders saatlerine, konulara değinilmiş ayrıca sosyal bilgiler ders kitaplarında coğrafya kavramları bağlamında yer alan konuların edebi ürün, soru, etkinlik, görsellik ve değerlendirme boyutlarına ilişkin bulgulara yer verilmiştir.

\section{SBÖP’de Yer Alan Beceriler}

Karasu Avcı ve Faiz'e (2018) göre beceri herhangi bir davranışı yapabilme durumudur ayrica sahip olunan beceriler hem bireysel hem de toplumsal problemlerin çözülmesinde etkilidir. MEB'in SBÖP'de belirlediği ve 4-7. sinıf öğrencilerinden kazanmasını beklediği toplam 27 beceri vardır. Bu doğrultuda MEB'in SBÖP'de belirlediği beceriler Tablo 2'de verilmiştir. 
Tablo 2. SBÖP’de Yer Alan Beceriler

\begin{tabular}{|c|c|c|}
\hline \multicolumn{3}{|c|}{ SBÖP'de Yer Alan Beceriler } \\
\hline Araştırma & Harita okuryazarlığ1 & Mekânı algılama \\
\hline Çevre okuryazarlığ & Hukuk okuryazarlığı & Öz denetim \\
\hline $\begin{array}{l}\text { Değişim ve sürekliliği } \\
\text { alg1lama }\end{array}$ & İletişim & Politik okuryazarlık \\
\hline Dijital okuryazarlık & İş birliği & Problem çözme \\
\hline Eleştirel düşünme & $\begin{array}{l}\text { Kalıp yarg1 ve } \\
\text { önyargıı1 fark etme }\end{array}$ & Sosyal katılım \\
\hline Empati & Kanit kullanma & $\begin{array}{lrl}\text { Tablo, } & \text { grafik } & \text { ve } \\
\text { diyagram çizme } & \text { ve } \\
\text { yorumlama } & & \end{array}$ \\
\hline Finansal okuryazarlık & Karar verme & $\begin{array}{l}\text { Türkçeyi doğru, güzel } \\
\text { ve etkili kullanma }\end{array}$ \\
\hline Girişimcilik & Konum analizi & Yenilikçi düşünme \\
\hline Gözlem & Medya okuryazarllğ 1 & $\begin{array}{l}\text { Zaman ve kronolojiyi } \\
\text { alg1lama }\end{array}$ \\
\hline
\end{tabular}

Kaynak: (MEB, 2018)

Tablo 2'ye verilen 27 beceriden sadece dördü coğrafya ile doğrudan ilişkilendirilebilirken beşi de coğrafya ile dolaylı olarak ilişkilendirilebilecek düzeydedir. Bu doğrultuda "çevre okuryazarlığı, harita okuryazarlığı, konum analizi ve mekânı algılama" becerileri coğrafya ile doğrudan ilişkiliyken "araştırma, gözlem, kanıt kullanma, tablo, grafik ve diyagram çizme ve yorumlama" gibi beceriler de coğrafya ile dolaylı olarak ilişkilendirilebilecek niteliktedir.

\section{SBÖP'de Yer Alan Öğrenme Alanları ve Öğrenme Alanlarının İlgili Olduğu Disiplinler}

MEB'e (2018) öğrenme alanlarını, birbiriyle bağlantılı olan bilgi, beceri ve değerlerin bir bütün olarak görülebildiği ve öğrenmeyi organize eden disiplinler arası bir yapı olarak tanımlamaktadır. Bu doğrultuda SBÖP'de yer alan 4-7. sınıf sosyal bilgiler dersi için belirlenen yedi öğrenme alanı ve bu ögrenme alanlarının ilgili oldukları disiplinler Tablo 3 ’te verilmiştir.

Tablo 3. SBÖP'de Yer Alan Öğrenme Alanlarının İlgili Olduğu Disiplinler

\begin{tabular}{ll}
\hline Öğrenme Alanları & $\begin{array}{l}\text { Öğrenme Alanlarının İlgili Olduğu } \\
\text { Disiplinler }\end{array}$ \\
\hline 1. Birey ve Toplum & $\begin{array}{l}\text { Hukuk, Psikoloji, Sosyoloji, Tarih ve } \\
\text { Vatandaşlık } \\
\text { 2. Kültür ve Miras }\end{array}$ \\
Tarih, Kültür ve Türk kültürü
\end{tabular}


3. İnsanlar, Yerler ve

Çevreler

4. Bilim, Teknoloji ve

Toplum

5. Üretim, Dağıtım ve

Tüketim

6. Etkin Vatandaşlık

7. Küresel Bağlantılar
Coğrafya ve Çevre eğitimi

Bilim, Teknoloji ve Sosyoloji

Coğrafya, Ekonomi ve Meslek bilgisi

Sosyoloji, Siyaset bilimi ve Hukuk

Coğrafya, Vatandaşlık, Tarih ve Siyaset

Tablo 3 incelendiğinde SBÖP'de yer verilen yedi öğrenme alanı içinde birçok sosyal bilim disiplini yer almaktadır. SBÖP'de yer alan öğrenme alanları ve 4-7. sınıf sosyal bilgiler ders kitapları incelendiğinde İnsanlar, Yerler ve Çevreler (IYYÇ) öğrenme alanı bütünüyle coğrafya kavramları kapsamında yer alırken Üretim, Dağıtım ve Tüketim (ÜDT) ve Küresel Bağlantılar (KB) öğrenme alanları ise kısmen coğrafya kavramları ile ilişkilidir.

\section{SBÖP'de Yer Alan Coğrafya Kavramları Kapsamındaki Dördüncü Sınıf Sosyal Bilgiler Dersi Kazanımları ve Ders Saatleri}

Dördüncü sınıf sosyal bilgiler dersinde toplam 7 öğrenme alanı ve 33 kazanım vardır. Bu 7 öğrenme alanı ve 33 kazanım için belirlenen ders saati ise toplam 108 saattir. SBÖP'nin dördüncü sınıf IYYÇ, ÜDT ve KB öğrenme alanlarında coğrafya kavramları kapsamında yer alan kazanımlar ve ders saatleri Tablo 4'te verilmiştir.

Tablo 4. Dördüncü Sınıf Sosyal Bilgiler Dersi İYÇ, ÜDT ve KB Öğrenme Alanı Kazanımları ve Ders Saatleri

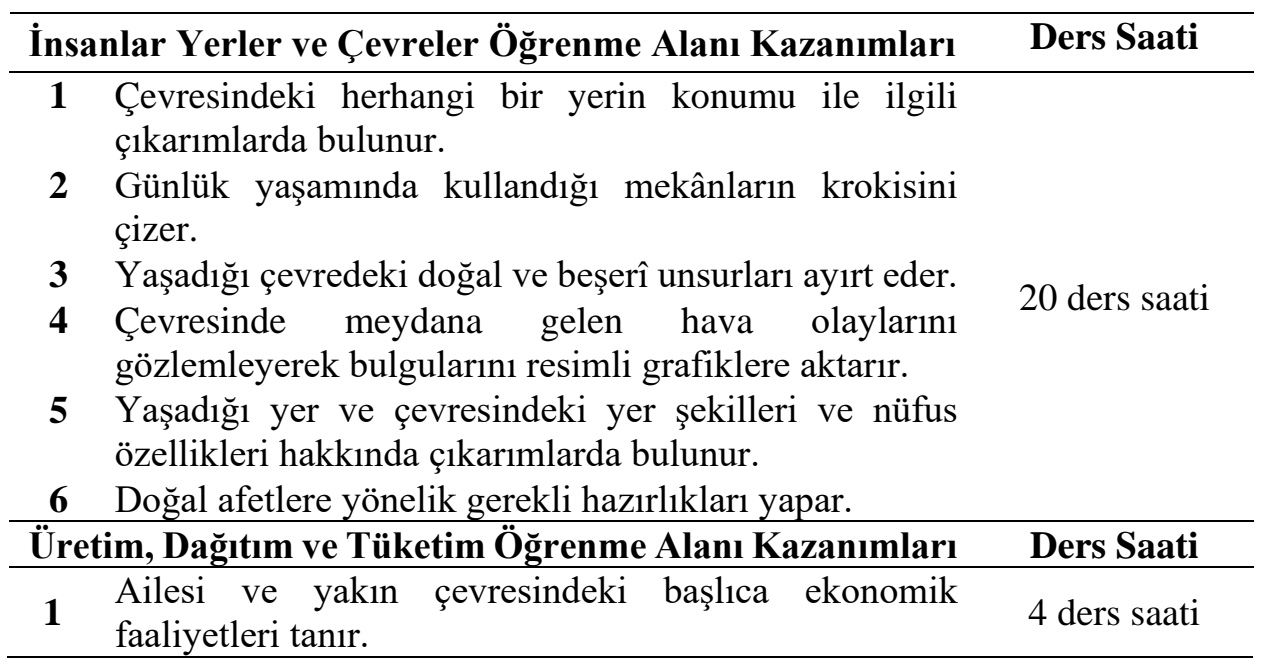




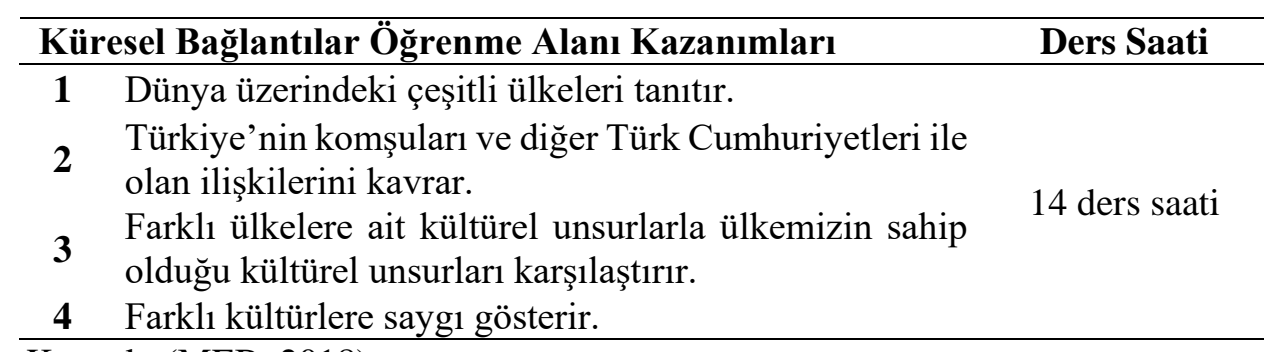

Kaynak: (MEB, 2018)

Tablo 4'e göre dördüncü sınıf sosyal bilgiler dersi IYYÇ, ÜDT ve KB öğrenme alanları için 11 kazanım belirlenmiş ve bu kazanımlar için ise 38 ders saati öngörülmüștür. Belirlenen bu kazanımların tamamı coğrafya kavramları ile ilişkilidir. Kazanımlar, ders içeriği ve ders saatleri bir bütün halinde incelendiğinde ders içeriklerinin kazanımlarla uyumlu ve ders saatlerinin yeterli düzeyde olduğu söylenebilir. Kazanımların en fazla olduğu öğrenme alanı IYYÇ öğrenme alanı iken en az olduğu öğrenme alanı ise ÜDT'dir. İYÇ öğrenme alanının kazanımları; konum, kroki, doğal ve beşeri unsurlar, hava olayları, yer şekilleri, nüfus gibi coğrafya kavramları ile ilgilidir. ÜDT öğrenme alanındaki kazanımlardan sadece biri coğrafya kavramları kapsamında yer alan ekonomik faaliyetlerle ilişkilidir. KB öğrenme alanı için belirlenen kazanımlar ise coğrafya kavramları kapsamında yer alan ülkeler coğrafyası ile ilgilidir.

\section{Dördüncü Sınıf Sosyal Bilgiler Dersi Kitabı İYÇ, ÜDT ve KB Öğrenme Alanlarında Coğrafya Kavramları Kapsamında Yer Alan Konular}

Dördüncü sınıf sosyal bilgiler dersi İYÇ, ÜDT ve KB öğrenme alanlarında coğrafya kavramları kapsamında yer verilen konular Tablo 5'te verilmiştir.

Tablo 5. Dördüncü Sınıf Sosyal Bilgiler Ders Kitabı Öğrenme Alanlarında Coğrafya Kavramları Kapsamında Yer Alan Konular

\begin{tabular}{ll}
\hline İnsanlar Yerler ve Çevreler Öğrenme Alanı Konuları \\
\hline $\mathbf{1}$ & Yön belirleme ve herhangi bir yerin konumunu tarif etme \\
$\mathbf{2}$ & Yer tarifi ve kroki çizme \\
$\mathbf{3}$ & Çevredeki doğal ve beşerî unsurlar \\
$\mathbf{4}$ & Hava olayları ve resimli grafiklere çizme \\
$\mathbf{5}$ & Yaşadı̆̆ımız yerin fiziki ve siyasi haritalarda gösterimi \\
$\mathbf{6}$ & Doğal afetler (Heyelan, çı̆̆, sel, firtına ve deprem) \\
$\mathbf{7}$ & Deprem öncesinde, sırasında ve sonrasında yapılacaklar \\
\hline Üretim, Dağıtım ve Tüketim Öğrenme Alanı Konuları \\
\hline $\mathbf{1}$ & Türkiye'deki bazı ekonomik faaliyetler, üretim ve meslekler \\
\hline Küresel Bağlantılar Öğrenme Alanı Konuları \\
\hline $\mathbf{1}$ & Ülkeler coğrafyası (Finlandiya ve Ürdün)
\end{tabular}


2 Türkiye'nin komşuları (Bulgaristan, Yunanistan, Suriye, Irak, İran, Nahçıvan, Ermenistan ve Gürcistan)

3 Türk Cumhuriyetleri (Azerbaycan, Türkmenistan, Özbekistan, Kırgızistan, Kazakistan, Kuzey Kıbrıs Türk Cumhuriyeti)

4 Farklı kültürler (Macaristan ve Japonya)

5 Kültürel Farklılıklar (Türkiye, İskoçya, Çin, Şili, İngiltere, Hint ve Tayland)

Tablo 5 incelendiğinde 4. sınıf sosyal bilgiler dersi İYÇ, ÜDT ve KB öğrenme alanlarında yer alan konular (Konum, yön belirleme, harita, doğal ve beșeri unsurlar, hava olayları, doğal afetler, ekonomik faaliyetler, ülkeler ve kültür coğrafyası) coğrafya kavramlarıyla ile ilişkilendirilebilecek niteliktedir.

Dördüncü Sınıf Sosyal Bilgiler Ders Kitabı İYÇ, ÜDT ve KB Öğrenme Alanlarında Coğrafya Kavramları Kapsamında Yer Alan Konuların Edebi Ürün, Soru, Etkinlik, Görsellik ve Ölçme-Değerlendirme Boyutu

Dördüncü sınıf sosyal bilgiler ders kitabı İYÇ, ÜDT ve KB öğrenme alanlarında coğrafya kavramları kapsamında yer alan konuların edebi ürün, soru, etkinlik, görsellik ve ölçme-değerlendirme boyutları Tablo 6'da verilmiştir.

Tablo 6. Dördüncü Sınıf Sosyal Bilgiler Ders Kitabı İYÇ, ÜDT ve KB Öğrenme Alanlarında Coğrafya Kavramları Kapsamında Yer Alan Konuların Edebi Ürün, Soru, Etkinlik, Görsellik ve Ölçme-Değerlendirme Özellikleri

\begin{tabular}{lcccccc}
\hline Öğrenme Alanları & $\begin{array}{c}\text { Edebi } \\
\text { Ürün }\end{array}$ & Soru & Etkinlik & $\begin{array}{c}\text { Görsel } \\
\text { Öge }\end{array}$ & $\begin{array}{c}\text { Ölçme- } \\
\text { Değerlendirme }\end{array}$ \\
\hline $\begin{array}{l}\text { İnsanlar, Yerler } \\
\text { Çevreler }\end{array}$ & ve & 3 & 21 & 8 & 42 & 1 \\
$\begin{array}{l}\text { Urretim, Dağıtım } \\
\text { Tüketim ve }\end{array}$ & - & 4 & 2 & 7 & 1 \\
Küresel Bağlantılar & - & 15 & 1 & 39 & 1 \\
\hline
\end{tabular}

Tablo 6 incelendiğinde belirlenen öğrenme alanlarının ders içeriklerinde yer alan edebi ürünlerin yetersiz olduğu söylenebilir. Ancak ders içeriğinde yer alan sorular, ders içi ve dışı etkinlikler belirlenen kazanımlarla ilişkilidir ve ders içeriklerinin görsel açıdan (resim, harita ve fotoğraf) oldukça zengin olduğu söylenebilir. Öğrenme alanları sonunda verilen ölçme-değerlendirme farklı soru tipleriyle (Boşluk doldurma, doğru-yanlış, çoktan seçmeli, eşleştirme ve açık uçlu sorularla) hazırlanmıştır. Ancak öğrenme alanları sonunda öğrenci öz değerlendirmesine veya kavram öğretimine yer verilmemiştir. 


\section{SBÖP'de Yer Alan Coğrafya Kavramları Kapsamındaki Beşinci Sınıf} Sosyal Bilgiler Dersi Kazanımları ve Ders Saatleri

Beşinci sınıf sosyal bilgiler dersinde toplam 7 öğrenme alanı ve 33 kazanım vardır. Bu doğrultuda SBÖP; IYYÇ, ÜDT ve KB öğrenme alanlarındaki coğrafya kavramları kapsamında yer alan kazanımlar ve ders saatleri Tablo 7'de verilmiştir.

Tablo 7. Beşinci Sınıf Sosyal Bilgiler Dersi IYYÇ, ÜDT ve KB Öğrenme Alanı Coğrafya Kavramları Kapsamında Yer Alan Kazanımlar ve Ders Saatleri

\begin{tabular}{|c|c|}
\hline İnsanlar Yerler ve Çevreler Öğrenme Alanı Kazanımları & Ders saati \\
\hline $1 \begin{array}{l}\text { Haritalar üzerinde yaşadığı yer ve çevresinin yeryüzü } \\
\text { sekillerini genel olarak açılar. }\end{array}$ & \multirow{5}{*}{$\begin{array}{l}18 \text { ders } \\
\text { saati }\end{array}$} \\
\hline $\begin{array}{l}2 \text { Yaşadığ çevrede görülen iklimin, insan faaliyetlerine } \\
\text { etkisini, günlük yaşantısından örnekler vererek açıklar. }\end{array}$ & \\
\hline $\begin{array}{l}3 \text { Yaşadığı yer ve çevresindeki doğal özellikler ile beşerî } \\
\text { özelliklerin nüfus ve yerleşme üzerindeki etkilerine örnekler } \\
\text { verir. }\end{array}$ & \\
\hline $\begin{array}{l}4 \text { Yaşadığ } 1 \text { çevredeki afetlerin ve çevre sorunlarının oluşum } \\
\text { nedenlerini sorgular. }\end{array}$ & \\
\hline $\begin{array}{l}5 \text { Doğal afetlerin toplum hayatı üzerine etkilerini örneklerle } \\
\text { açıklar. }\end{array}$ & \\
\hline Üretim, Dağıtım ve Tüketim Öğrenme Alanı Kazanımları & Ders saati \\
\hline $\begin{array}{l}\text { Yaşadığ } 1 \text { yerin ve çevresinin ekonomik faaliyetlerini analiz } \\
\text { eder. }\end{array}$ & \multirow{4}{*}{$\begin{array}{l}12 \text { ders } \\
\text { saati }\end{array}$} \\
\hline $\begin{array}{l}\text { Yaşadığı yer ve çevresindeki ekonomik faaliyetlere bağlı } \\
\text { olarak gelişen meslekleri tanır. }\end{array}$ & \\
\hline $\begin{array}{l}\text { Çevresindeki ekonomik faaliyetlerin, insanların sosyal } \\
\text { hayatlarına etkisini analiz eder. }\end{array}$ & \\
\hline $\begin{array}{l}\text { Temel ihtiyaçları karşılamaya yönelik ürünlerin üretim, } \\
\text { dağıtım ve tüketim ağını analiz eder }\end{array}$ & \\
\hline Küresel Bağlantılar Öğrenme Alanı Kazanımları & Ders saati \\
\hline $\begin{array}{l}1 \text { Yaşadığ } 1 \text { yer ve çevresinin ülkemiz ile diğer ülkeler } \\
\text { arasındaki ekonomik ilişkilerdeki rolünü araştırır. }\end{array}$ & \multirow{3}{*}{$\begin{array}{c}11 \text { ders } \\
\text { saati }\end{array}$} \\
\hline $\begin{array}{l}2 \text { Ülkeler arasındaki ekonomik ilişkilerde iletişim ve ulaşım } \\
\text { teknolojisinin etkisini tartışır. }\end{array}$ & \\
\hline Turizmin uluslararası ilişkilerdeki önemini açıklar. & \\
\hline
\end{tabular}
Kaynak: (MEB, 2018)

Tablo 7’ye göre IYYÇ, ÜDT ve KB öğrenme alanlarındaki coğrafya kavramları kapsamında toplam 12 kazanım vardır ve bu kazanımlar için ise 41 ders saati 
belirlenmiştir. Kazanım ve ders saatinin en fazla olduğu öğrenme alanı İYÇ iken en az olduğu öğrenme alanı ise KB öğrenme alanıdır. IYYÇ öğrenme alanı için belirlenen kazanımlar; yeryüzü şekilleri, iklim, nüfus, yerleşme, doğal afetler ve çevre sorunları gibi coğrafya kavramları ile ilgilidir. ÜDT öğrenme alanı kazanımları coğrafya kavramları kapsamında yer alan; ekonomik faaliyetler, üretim, dağıtım ve tüketim konuları ile ilgilidir. KB öğrenme alanı kazanımları ülkeler arası ekonomik ilişkiler, ulaşım ve turizm gibi coğrafya kavramları ile ilgilidir.

\section{Beşinci Sınıf Sosyal Bilgiler Ders Kitabı IYYÇ, ÜDT ve KB Öğrenme Alanlarında Coğrafya Kavramları Kapsamında Yer Alan Konular}

Beşinci sınıf sosyal bilgiler ders kitabı IYYÇ, ÜDT ve KB öğrenme alanlarında coğrafya kavramları kapsamında yer alan konular Tablo 8'de verilmiştir.

Tablo 8. Beşinci Sınıf Sosyal Bilgiler Ders Kitabı İYÇ, ÜDT ve KB Öğrenme Alanlarında Coğrafya Kavramları Kapsamında Yer Alan Konular

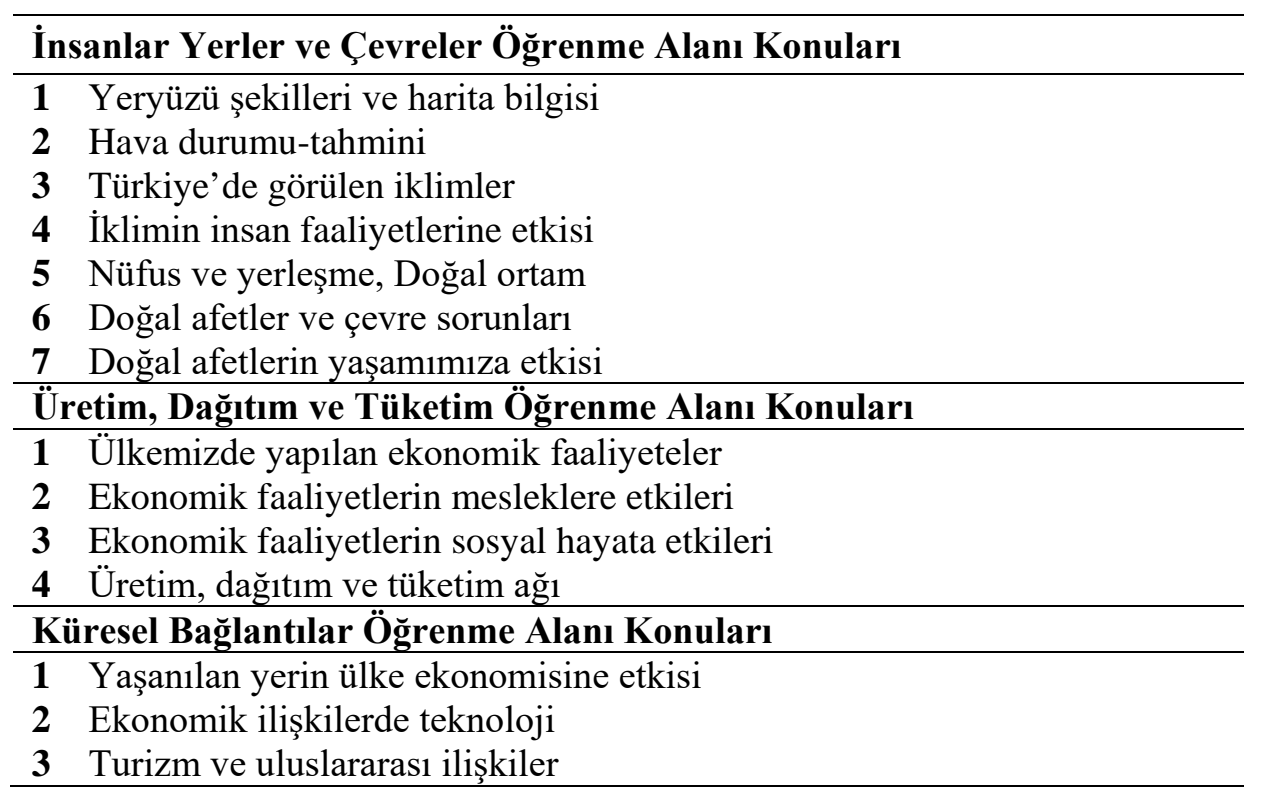

Tablo 8 incelendiğinde 5. sınıf sosyal bilgiler dersi IYYÇ, ÜDT ve KB öğrenme alanlarında yer alan 14 konu (yer şekilleri, harita bilgisi, hava durumu, iklim, Türkiye'de görülen iklimler, iklimin insan faaliyetlerine etkisi, nüfus ve yerleşme, doğal ortam, doğal afetler, ekonomik faaliyetler, ekonomik ilişkiler, turizm ve uluslararası ilişkiler) coğrafya kavramı ile ilişkilendirilebilecek niteliktedir. 
Beşinci Sınıf Sosyal Bilgiler Ders Kitabı İYÇ, ÜDT ve KB Öğrenme Alanlarında Coğrafya Kavramları Kapsamında Yer Alan Konuların Edebi Ürün, Soru, Etkinlik, Görsellik ve Değerlendirme Boyutu

Beşinci sınıf sosyal bilgiler ders kitabı IYYÇ, ÜDT ve KB öğrenme alanlarında coğrafya kavramları kapsamında yer alan konuların edebi ürün, soru, etkinlik, görsellik ve ölçme-değerlendirme boyutları Tablo 9'da verilmiştir.

Tablo 9. Beşinci Sınıf Sosyal Bilgiler Ders Kitabı IYYÇ, ÜDT ve KB Öğrenme Alanlarında Coğrafya Kavramları Kapsamındaki Konuların Edebi Ürün, Soru, Etkinlik, Görsellik ve Ölçme-Değerlendirme Özellikleri

\begin{tabular}{lcccccc}
\hline Öğrenme Alanları & $\begin{array}{c}\text { Edebi } \\
\text { Ürün }\end{array}$ & Soru & Etkinlik & $\begin{array}{c}\text { Görsel } \\
\text { Öge }\end{array}$ & $\begin{array}{c}\text { Ölçme- } \\
\text { Değerlendirme }\end{array}$ \\
\hline $\begin{array}{l}\text { Insanlar, Yerler } \\
\text { Chevreler ve }\end{array}$ & - & 12 & 11 & 50 & 1 \\
$\begin{array}{l}\text { Üretim, Dağıtım } \\
\text { Tüketim ve }\end{array}$ & - & 7 & 7 & 50 & 1 \\
Küresel Bağlantılar & - & 7 & 4 & 17 & 1 \\
\hline
\end{tabular}

Tablo 9 incelendiğinde belirlenen öğrenme alanlarının ders içeriklerinde edebi ürünlere hiç yer verilmemiştir. Ders içeriklerinde yer verilen sorular, ders içi ve dışı etkinlikler belirlenen kazanımlarla ilişkilidir. Ders içeriklerinin görsel (resim, harita ve fotoğraf) açından oldukça zengin olduğu söylenebilir. Ancak ÜDT ve KB öğrenme alanlarında soru ve etkinlik sayısında bir azalma olduğu görülmektedir. Öğrenme alanları sonunda verilen ölçme-değerlendirme farklı soru tipleriyle (Boşluk doldurma, doğru-yanlış, çoktan seçmeli, eşleştirme ve açık uçlu sorularla) hazırlanmıştır ancak öğrenme alanları sonunda öğrenci öz değerlendirmesine veya kavram öğretimine yer verilmemiştir.

SBÖP'de Yer Alan Coğrafya Kavramları Kapsamındaki Altıncı Sınıf Sosyal Bilgiler Dersi Kazanımları ve Ders Saatleri

Altıncı sınıf sosyal bilgiler dersinin 7 öğrenme alanı için 33 kazanım ve 108 ders saati belirlenmiş̧ir. Altıncı sınıf sosyal bilgiler dersinde coğrafya kavramları kapsamında IYYÇ, ÜDT ve KB öğrenme alanlarında yer alan kazanımlar ve ders saati Tablo 10'da verilmiştir. 
Tablo 10. Altıncı Sınıf Sosyal Bilgiler Dersi IYYC, ÜDT ve KB Öğrenme Alanı Coğrafya Kavramları Kapsamında Yer Alan Kazanımlar ve Ders Saatleri

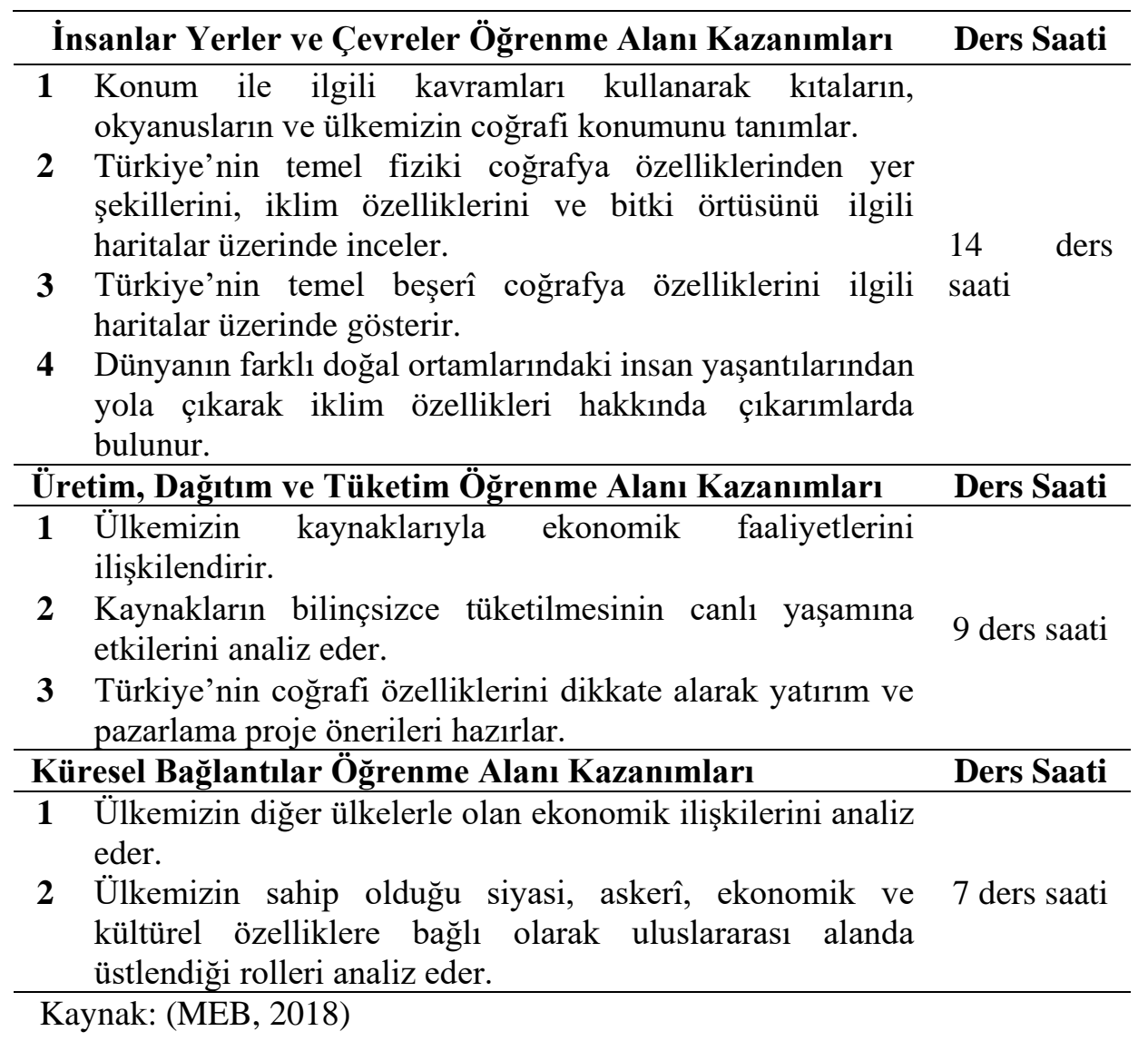

Tablo 10 incelendiğinde kazanımların en fazla olduğu öğrenme alanı İYÇ'dir. SBÖP'de coğrafya kapsamında yer alan İYÇ, ÜDT ve KB öğrenme alanlarında toplam 9 kazanım coğrafya kavramı ile ilişkilendirilmiş ve bu kazanımların gerçekleştirilebilmesi için 30 ders saati belirlenmiştir. IYYÇ öğrenme alanındaki kazanımlar; yer şekilleri, iklim, bitki örtüsü, kıtaların, okyanusların ve ülkemizin coğrafi konumu, Türkiye'nin temel beşerî coğrafya özellikleri ve dünya iklim tipleri gibi coğrafya kavramları ile ilgilidir. ÜDT öğrenme alanındaki kazanımlar; ülkemizin kaynaklarıyla ekonomik faaliyetleri, kaynakların bilinçsizce tüketilmesinin canlı yaşamına etkileri ve Türkiye'nin coğrafi özellikleri gibi coğrafya kavramları ile ilgilidir. KB öğrenme alanındaki kazanımlar; ülkemizin diğer ülkelerle olan ekonomik ilişkileri ve ülkemizin sahip olduğu siyasi, askerî, ekonomik ve kültürel özelliklere bağlı olarak uluslararası alanda üstlendiği roller gibi coğrafya kavramları ile ilgilidir. 
Altıncı Sınıf Sosyal Bilgiler Ders Kitabı İYÇ, ÜDT ve KB Öğrenme Alanlarında Coğrafya Kavramları Kapsamında Yer Alan Konular

Altıncı sınıf sosyal bilgiler ders kitabı İYÇ, ÜDT ve KB öğrenme alanlarındaki coğrafya kavramları kapsamında yer alan konular Tablo 11'de verilmiştir.

Tablo 11. Altıncı Sınıf Sosyal Bilgiler Ders Kitabı IYYÇ, ÜDT ve KB Öğrenme Alanlarında Coğrafya Kavramları Kapsamında Yer Alan Konular

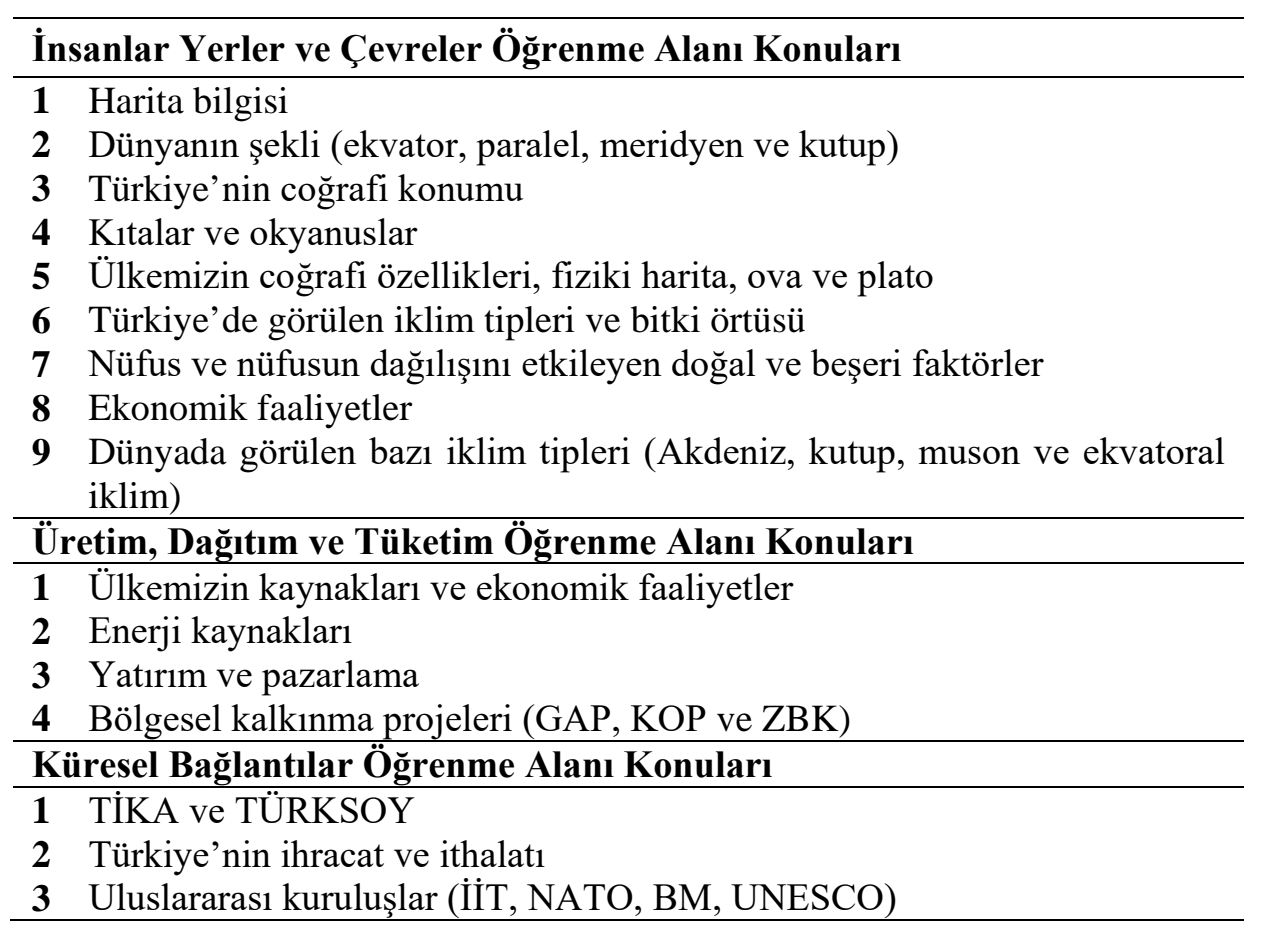

Tablo 11 incelendiğinde 6. sınıf sosyal bilgiler dersi IYYÇ, ÜDT ve KB öğrenme alanlarında yer alan 16 konu (Harita bilgisi, dünyanın şekli, kıtalar, okyanuslar, Türkiye'nin coğrafi konumu, ülkemizin coğrafi özellikleri, ülkemizde ve dünyada görülen iklim tipleri ve bitki örtüsü, nüfus, ekonomik faaliyetler, enerji kaynakları, bölgesel kalkınma projeleri, Türkiye'nin ihracat ve ithalatı ve uluslararası kuruluşlar) coğrafya kavramları ile ilişkilendirilebilecek niteliktedir. 
Altıncı Sınıf Sosyal Bilgiler Ders Kitabı İYÇ, ÜDT ve KB Öğrenme Alanlarında Coğrafya Kavramları Kapsamında Yer Alan Konuların Edebi Ürün, Soru, Etkinlik, Görsellik ve Değerlendirme Boyutu

Altıncı sınıf sosyal bilgiler ders kitabı IYYÇ, ÜDT ve KB öğrenme alanlarında coğrafya kavramları kapsamında yer alan konuların edebi ürün, soru, etkinlik, görsellik ve ölçme-değerlendirme boyutları Tablo 12'de verilmiştir.

Tablo 12. Altıncı Sınıf Sosyal Bilgiler Ders Kitabı IYYÇ, ÜDT ve KB Öğrenme Alanlarında Coğrafya Kavramları Kapsamındaki Konuların Edebi Ürün, Soru, Etkinlik, Görsellik ve Ölçme-Değerlendirme Özellikleri

\begin{tabular}{lcccccc}
\hline Öğrenme Alanları & $\begin{array}{c}\text { Edebi } \\
\text { Ürün }\end{array}$ & Soru & Etkinlik & $\begin{array}{c}\text { Görsel } \\
\text { Öge }\end{array}$ & $\begin{array}{c}\text { Ölçme- } \\
\text { Değerlendirme }\end{array}$ \\
\hline $\begin{array}{l}\text { İnsanlar, Yerler } \\
\text { Çevreler ve }\end{array}$ & - & 13 & 15 & 30 & 1 \\
$\begin{array}{l}\text { Üretim, Dağıtım } \\
\text { Tüketim ve }\end{array}$ & - & 13 & 7 & 25 & 1 \\
Küresel Bağlantılar & - & 13 & 7 & 15 & 1 \\
\hline
\end{tabular}

Tablo 12 incelendiğinde belirlenen öğrenme alanlarında edebi ürünlere hiç yer verilmezken ders içeriklerinde yer alan sorular, ders içi ve dışı etkinlikler belirlenen kazanımlarla ilişkilidir ve ders içeriklerinin görsel (resim, harita ve fotoğraf) açıdan oldukça zengin olduğu söylenebilir. Ancak soru ve etkinlik sayısının ise az olduğu söylenebilir. Öğrenme alanları sonunda verilen ölçmedeğerlendirme farklı soru tipleriyle (Boşluk doldurma, çoktan seçmeli, eşleştirme ve açık uçlu sorularla) hazırlanmıştır. Öğrenme alanları sonunda öğrenci öz değerlendirmesi yoktur ancak "oynayalım-öğrenelim" şeklinde kavram ögretimine yer verilmiştir.

\section{SBÖP'de Yer Alan Coğrafya Kavramları Kapsamındaki Yedinci Sınıf Sosyal Bilgiler Dersi Kazanımları ve Ders Saatleri}

Yedinci sınıf sosyal bilgiler dersinde yedi öğrenme alanı için belirlenen 31 kazanım vardır ve bu kazanımlar için belirlenen ders saati 108 ders saatidir. 7 . sınıf sosyal bilgiler dersinde coğrafya kavramları kapsamında yer alan IYYÇ, ÜDT ve KB öğrenme alanı kazanımları ve ders saatleri Tablo 13'te verilmiştir. 
Tablo 13. Yedinci Sınıf Sosyal Bilgiler Dersi İYÇ, ÜDT ve KB Öğrenme Alanı Coğrafya Kavramları Kapsamında Yer Alan Kazanımlar ve Ders Saatleri

\begin{tabular}{|c|c|}
\hline İnsanlar Yerler ve Çevreler Öğrenme Alanı Kazanımları & Ders Saati \\
\hline 1 Örnek incelemeler $\begin{array}{l}\text { yoluyla } \\
\text { yerleşmeyi etkileyen } \\
\text { faktörler } \\
\text { bulunur. }\end{array}$ & \\
\hline $\begin{array}{l}\text { Türkiye'de nüfusun dağılışını etkileyen faktörlerden } \\
\text { hareketle Türkiye'nin demografik özelliklerini yorumlar. }\end{array}$ & 12 ders saati \\
\hline $\begin{array}{l}3 \text { Örnek incelemeler yoluyla göçün neden ve sonuçlarını } \\
\text { tartışır. }\end{array}$ & \\
\hline Üretim, Dağıtım ve Tüketim Öğrenme Alanı Kazanımları & Ders Saati \\
\hline $\begin{array}{l}1 \text { Üretimde ve yönetimde toprağın önemini geçmişten ve } \\
\text { günümüzden örneklerle açıklar. } \\
2 \text { Üretim teknolojisindeki gelişmelerin sosyal ve ekonomik } \\
\text { hayata etkilerini değerlendirir. }\end{array}$ & 5 ders saati \\
\hline Küresel Bağlantılar Öğrenme Alanı Kazanımları & Ders Saati \\
\hline $\begin{array}{l}1 \text { Türkiye'nin üyesi olduğu uluslararası kuruluşlara örnekler } \\
\text { verir. } \\
2 \text { Türkiye'nin ilişkide olduğu ekonomik bölge ve kuruluşları } \\
\text { tanır. }\end{array}$ & 6 ders saati \\
\hline
\end{tabular}

Kaynak: (MEB, 2018)

Tablo 13'e göre yedinci sınıf sosyal bilgiler dersi IYYÇ, ÜDT ve KB öğrenme alanlarında coğrafya kavramları ile ilişkilendirilen toplam yedi kazanım vardır ve bu kazanımlar için belirlenen 23 ders saatidir. Kazanımların en fazla olduğu öğrenme alanı İYÇ öğrenme alanı iken en az olduğu öğrenme alanı ise ÜDT ve KB öğrenme alanlarıdır. Kazanımlar incelendiğinde İYÇ öğrenme alanı; nüfus, yerleşme ve göç gibi coğrafya kavramları ile ilgilidir. ÜDT öğrenme alanı üretim ve toprak gibi coğrafya kavramları ile ilgilidir. KB öğrenme alanındaki kazanımlar; Türkiye'nin üye olduğu uluslararası kuruluşlar ve Türkiye'nin ilişkide olduğu ekonomik bölge ve kuruluşlar gibi coğrafya kavramları ile ilgilidir.

\section{Yedinci Sınıf Sosyal Bilgiler Ders Kitabı İYÇ, ÜDT ve KB Öğrenme Alanlarında Coğrafya Kavramları Kapsamında Yer Alan Konular}

Yedinci sınıf sosyal bilgiler ders kitabı IYYC, ÜDT ve KB öğrenme alanlarında coğrafya kavramları kapsamında yer alan konular Tablo 14'te verilmiştir. 
Tablo 14. Yedinci Sınıf Sosyal Bilgiler Ders Kitabı IYYÇ, ÜDT ve KB Öğrenme Alanında Coğrafya Kavramları Kapsamında Yer Alan Konular

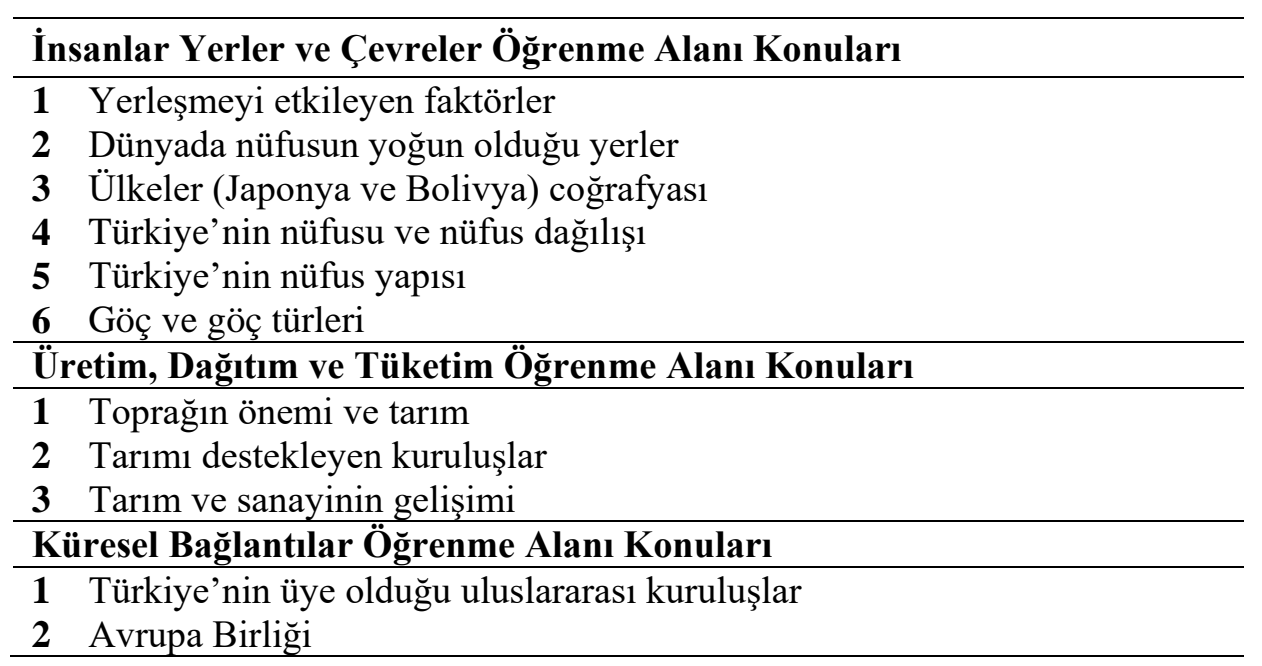

Tablo 14 incelendiğinde 7. sınıf sosyal bilgiler dersi IYÇ, ÜDT ve KB öğrenme alanlarında yer alan 11 konu (Yerleşme, ülkeler coğrafyası, Türkiye'nin nüfusu, nüfus dağılışı ve nüfus yapısı, göç ve göç türleri, toprak, tarım, tarımı destekleyen kuruluşlar, sanayi, uluslararası kuruluşlar) coğrafya kavramları ile ilişkilendirilebilecek niteliktedir.

Yedinci Sınıf Sosyal Bilgiler Ders Kitabı İYÇ, ÜDT ve KB Öğrenme Alanlarında Coğrafya Kavramları Kapsamında Yer Alan Konuların Edebi Ürün, Soru, Etkinlik, Görsellik ve Değerlendirme Boyutu

Yedinci sınıf sosyal bilgiler dersi kitabı IYYÇ, ÜDT ve KB öğrenme alanlarında coğrafya kavramları kapsamında yer alan konuların edebi ürün, soru, etkinlik, görsellik ve ölçme-değerlendirme boyutları Tablo 15'te verilmiştir.

Tablo 15. Yedinci Sınıf Sosyal Bilgiler Ders Kitabı İYÇ, ÜDT ve KB Öğrenme Alanlarında Coğrafya Kavramları Kapsamındaki Konuların Edebi Ürün, Soru, Etkinlik, Görsellik ve Ölçme-Değerlendirme Özellikleri

\begin{tabular}{lcccccc}
\hline Öğrenme Alanları & $\begin{array}{c}\text { Edebi } \\
\text { Ürün }\end{array}$ & Soru & Etkinlik & $\begin{array}{c}\text { Görsel } \\
\text { Öge }\end{array}$ & $\begin{array}{c}\text { Ölçme- } \\
\text { Değerlendirme }\end{array}$ \\
\hline $\begin{array}{l}\text { İnsanlar, Yerler } \\
\begin{array}{l}\text { Çevreler } \\
\text { Üretim, De }\end{array}\end{array}$ Dağıtım & ve & 1 & 22 & 16 & 39 & 1 \\
Tüketim & & 1 & 9 & 10 & 7 & 1
\end{tabular}




\begin{tabular}{llllll} 
Küresel Bağlantılar & - & 11 & 6 & 17 & 1 \\
\hline
\end{tabular}

Tablo 15 incelendiğinde belirlenen öğrenme alanlarının ders içeriklerinde yer alan edebi ürünler, sorular, ders içi ve dışı etkinlikler belirlenen kazanımlarla ilişkilidir ve ders içeriklerinin görsel (resim, harita ve fotoğraf) açıdan oldukça zengin olduğu söylenebilir ancak soru ve etkinlik sayısının ise ÜDT ve KB öğrenme alanlarında daha az olduğu görülmektedir. Öğrenme alanları sonunda verilen ölçme-değerlendirme farklı soru tipleriyle (Boşluk doldurma, doğru yanlış, çoktan seçmeli, eşleştirme ve açık uçlu sorular ve bulmaca) hazırlanmıştır. Her öğrenme alanı sonunda öğrenci öz değerlendirmesi vardır ancak kavram öğretimine yer verilmemiştir.

\section{SBÖP’de Yer Alan 4-7. Sınıf Düzeyindeki Tüm Kazanımların ve Ders Saatlerinin Coğrafya Kavramları Kapsamındaki Oranları}

SBÖP'de yer alan sosyal bilgiler dersi 4-7. sınıf düzeyindeki tüm öğrenme alanlarında coğrafya kavramları kapsamında yer alan kazanımlara ve ders saatlerine Tablo 16'da yer verilmiştir.

Tablo 16. SBÖP'de 4-7. Sınıf Düzeyindeki Tüm Öğrenme Alanlarında

Coğrafya Kavramları Kapsamında Yer Alan Kazanımlar ve Ders Saatleri

\begin{tabular}{ccccccc}
\hline \multirow{2}{*}{$\begin{array}{c}\text { Sinıf } \\
\text { Düzeyi }\end{array}$} & \multicolumn{2}{c}{ SBÖP (4-7.Sinıf) } & \multicolumn{4}{c}{$\begin{array}{c}\text { Coğrafya Kavramları Kapsamındaki } \\
\text { Kazanımlar ve Ders Saatleri }\end{array}$} \\
\cline { 2 - 7 } & $\begin{array}{c}\text { Kazanıml } \\
\text { ar }\end{array}$ & $\begin{array}{c}\text { Ders } \\
\text { Saati }\end{array}$ & Kazanımlar & \% & $\begin{array}{c}\text { Ders } \\
\text { Saati }\end{array}$ & \% \\
\hline 4. Sinıf & 33 & 108 & 11 & 33,3 & 38 & 35,1 \\
5. Sinıf & 33 & 108 & 12 & 36,3 & 41 & 37,9 \\
6. Sinıf & 34 & 108 & 9 & 26,4 & 30 & 27,7 \\
7. Sinıf & 31 & 108 & 7 & 22,5 & 23 & 21,2 \\
\hline TOPLAM & 131 & 432 & 39 & 29,7 & 132 & 30,5 \\
\hline
\end{tabular}

Tablo 16 incelendiğinde SBÖP'de 4-7. sınıf düzeyindeki tüm öğrenme alanlarında yer alan kazanımlar toplam 131 tanedir ve bu kazanımlar için belirlenen ders saati ise 432 saattir. SBÖP'de 4-7. sınıf düzeyindeki öğrenme alanlarında coğrafya kavramları kapsamında yer alan tüm kazanımların oranı $\% 29,7$ iken ders saati oranı ise 30,5 'tir. 
$\underline{\text { T. Kacar-B. Bulut } \quad \text { Sosval Bilgiler Öğretim Programı ve 4-7. Sınıf... }}$

\section{SONUÇ, TARTIŞMA VE ÖNERILER}

Sosyal Bilgiler Öğretim Programı (SBÖP)'nda yer alan 27 beceriden sadece 4'ü doğrudan coğrafya kavramları ile ilgilidir. SBÖP'de yer alan yedi öğrenme alanından sadece İnsanlar, Yerler ve Çevreler (IYYÇ) coğrafya kavramları ile bütünüyle ilgiliyken Üretim, Dağıtım ve Tüketim (ÜDT) ve Küresel Bağlantılar (KB) öğrenme alanları ise kısmen coğrafya kavramları ile ilgilidir. SBÖP'de kazanımların en fazla olduğu öğrenme alanı İYÇ öğrenme alanıdır. SBÖP'de 47. sınıf düzeyindeki tüm öğrenme alanlarında yer alan kazanımlar toplam 131 tane ve ders saati ise 432'dir. SBÖP'de 4-7. sınıf düzeyindeki öğrenme alanlarında coğrafya kavramları bağlamında yer alan tüm kazanımların oranı $\% 29,7$ iken ders saati oranı ise 30,5'tir. SBÖP 4-7. sinıf sosyal bilgiler dersinde coğrafya kavramları bağlamında İYÇ, ÜDT ve KB öğrenme alanları için toplam 39 kazanım belirlenmiş ve bu kazanımların gerçekleştirilmesi için 132 ders saati belirlenmiştir. İYÇ, ÜDT ve KB öğrenme alanlarında belirlenen 39 kazanımın tamamı coğrafya kavramları ile ilgilidir. Bu kazanımların gerçekleştirilmesi için öngörülen ders saati (132 saat) yeterli düzeydedir. İYÇ, ÜDT ve KB öğrenme alanlarında yer alan konuların ve kazanımların önemli bir bölümü coğrafya kavramları ile ilişkilendirilebilecek niteliktedir. IYYÇ, ÜDT ve KB öğrenme alanlarının ders içeriklerinde yer alan edebi ürünler yetersizdir ancak sorular ve etkinlikler belirlenen kazanımlarla ilişkili ve yeterlidir. Ders içerikleri görsel açıdan oldukça zengindir ve öğrenme alanlarının sonunda verilen ölçmedeğerlendirmeler farklı soru tipleriyle hazırlanmıştır. Sadece 7. sınıf sosyal bilgiler dersi İYÇ öğrenme alanında öğrenci öz değerlendirmesi vardır. Ayrıca 4 ve 5. sınıf sosyal bilgiler ders kitaplarında "öğrenme alanı" kavramı kullanılırken 6 ve 7. sınıf sosyal bilgiler ders kitaplarında ise öğrenme alanı kavramı yerine "ünite" kavramı kullanılmıştır.

SBÖP'de yer alan 27 beceriden sadece dördü doğrudan coğrafya ile ilgilidir ancak bu becerilerin SBÖP'de öğrencilere nasıl kazandırılacağına dair bir bilgiye rastlanmamıştır. Gümüş, Akyol, Avcı ve Dikicigil'e (2019) göre öğretim programının vazgeçilmez ögelerinden olan becerilerin öğrencilere kazandırılmasında öğretim sürecinde rol üstlenen birçok etken vardır ve bu etkenlerin en önemlilerinden biri de ders kitaplarıdır ayrıca ders kitaplarının içeriğinin, becerilerin kazandırılması üzerindeki etkisi hem öğrenci hem de rehber olarak öğretmen açısından göz ardı edilemez. Bu bağlamda öğretmenlerin ve ders kitaplarının öğretim programlarında belirlenen becerileri öğrencilere kazandırmada oldukça önemli rollerinin olduğu söylenebilir.

Can (2019) yaptığ çalışmada 2005 SBÖP'yi incelemiş ve bu çalışma sonuçlarına göre; 2005 SBÖP'de 175 adet kazanım bulunurken SBÖP'de 131 kazanıma yer verildiği belirlenmiş, SBÖP'de kazanımlar yaklaşık olarak \%25 oranında azaltılmış ve sınıf düzeylerine göre kazanımlar dördüncü ve beşinci 
sınıflarda yaklaşık \%29, altıncı ve yedinci sınıflarda yaklaşı \%20 oranında azaltılmıştır. Çoban ve Akşit (2018) ve Selvi (2018) yaptıkları çalışmada benzer bir sonuca ulaşmıştır. Bu bağlamda SBÖP'de yer verilen kazanımların az olduğunu söylemek mümkündür hatta kazanımların sayısının daha fazla olabileceği de ifade edilebilir. Ancak burada önemli olan kazanımların sayısından ziyade içeriği olmalıdır. Zira kazanımların sayısı azaltılmış olabilir ancak mühim olan kazanımların ders içeriğini ve kapsamını yansıtmasıdır.

Ünal ve Özkaral (2019) SBÖP ile ders kitaplarının harita kullanımı açısından incelenmesine yönelik yaptıkları çalışmada SBÖP'de kazanımlarda harita kullanımına yönelik beceriler ve bu beceriler doğrultusunda ders kitaplarındaki haritalara ilişkin bilgilere yer verilmediğini düşünmektedir. Oysa SBÖP’de yer alan coğrafya kapsamında çevre okuryazarlığı, harita okuryazarlığ analizi ve mekânı algılama becerilerinin yer aldığı görülebilir. Ayrıca 6. sınıf sosyal bilgiler dersinde "Konum ile ilgili kavramları kullanarak kıtaların, okyanusların ve ülkemizin coğrafi konumunu tanımlar.", 5. sinıfta da "Haritalar üzerinde yaşadığ̣ yer ve çevresinin yeryüzü şekillerini genel olarak açıklar.” gibi kazanımlar yer almaktadır.

Sağdıç'a (2019) göre SBÖP'de yer alan disiplinler ve sosyal bilimlerin çok farklı alanlarından elde edilen bilgiler disiplinler arası ve bütünleşik bir yaklaşımla doğrultusunda ele alınmıştır. SBÖP'de yer verilen disiplinlerin yer alma oranı ise oldukça farklılık göstermektedir. Turan (2019) yaptığ çalışmada SBÖP'de coğrafyanın yer alma oranını $\% 28,57$ oranında belirlerken bu çalışmada da bu oran \%29,7 civarında bulunmuştur. Dolayısıyla bu sonuçların birbirine oldukça yakın olduğu ve birbiriyle önemli ölçüde örtüştüğü söylenebilir.

Turan (2019) SBÖP ile ilgili yaptığı çalışmada ÜDT öğrenme alanını ve kazanımlarını coğrafya ile ilişkilendirmemiştir. Ancak bu çalışmada SBÖP kazanımları, sosyal bilgiler ders kitapları ve ders içerikleri bir bütün halinde incelendiğinde ÜDT öğrenme alanının önemli ölçüde coğrafya ile ilişkilendirilebileceği görülmüş̧ür. Kızılçaoğlu ve Taş'a (2007) göre 6 ve 7. sınıf sosyal bilgiler dersinde coğrafya disiplini ile ilgili kazanımlara yer veren öğrenme alanları IYYÇ, ÜDT ve KB öğrenme alanlarıdır. Karatekin ve Sönmez'e (2016) göre SBÖP'de ağırlıklı olarak İYÇ ve ÜDT başta olmak üzere tüm öğrenme alanlarında coğrafya ile ilgili kazanım ve konulara yer verilmiştir. Bu sonuçların yapılan bu çalışma sonuçlarıyla da önemli ölçüde örtüştüğü söylenebilir.

Turan (2019) SBÖP ile ilgili yaptığı çalışmada SBÖP'de 4-7. sınıflarda yer alan öğrenme alanlarının diğer disiplinlerle olan ilişkisini belirlediği araştırma sonucu bu araştırma sonucuyla da önemli ölçüde örtüşmektedir. Zira her iki çalışmada da öğrenme alanlarının ilişkili olduğu disiplinlerin birbirine oldukça yakın olduğu söylenebilir. 
Dursun'un (2019) SBÖP'ye ilişkin öğretmen ve akademisyenlerin görüşlerini incelediği çalışmada akademisyenlerin tamamı SBÖP'de yer alan becerilerin çağın gereksinimlerine uygun şekilde hareket edebilecek, bilinçli ve uyum sağlayabilen bireyler yetiştirmek üzere belirlenen beceriler olduğunu ifade etmiştir. Turan (2019) yaptığ çalışmada SBÖP'de yer alan IYYÇ ve KB öğrenme alanlarındaki bazı becerileri coğrafya ile ilişki olduğunu belirlemiştir. Yapılan bu çalışma sonucunda da benzer bir sonuca ulaşılmıştır. Ancak Turan (2019) ÜDT öğrenme alanında yer alan bazı becerileri ise coğrafya ile ilişkilendirmemiştir. Yapılan bu çalışma sonucunda ÜDT öğrenme alanı için öngörülen bazı beceriler coğrafya ile ilişkilendirilebilecek düzeydedir.

Bebe ve Ünlü (2012) yaptıkları çalışmada sosyal bilgiler öğretmenleri, 6. sınıf SBÖP'de coğrafya içerikli ögelerin başarılı bir biçimde belirlendiğini düşünmekte, öğretmenlerin yarıya yakını coğrafya içerikli kazanımların kendi aralarında tutarlı ve her kazanımın daha sonraki kazanımın oluşumuna destek dizilimine sahip olduğunu ancak tüm bunlara karşın SBÖP'de coğrafyaya yeterli payın ayrılmadığını düşünmektedir. Bebe ve Ünlü’nün (2012) yaptığı çalışmayla bu çalışma sonuçları önemli ölçüde örtüşmektedir ancak Bebe ve Ünlü’nün (2012) yaptığı çalışmada yer alan öğretmenler coğrafyanın payının SBÖP'de yeterli olmadığını düşünmektedirler ancak yapılan bu çalışma sonuçlarına göre; disiplinler arası bir yaklaşımla hazırlanan SBÖP'de birçok sosyal bilimler disiplinin olduğu düşünüldüğünde coğrafyanın payı yaklaşık olarak \%29'dur. $\mathrm{Bu}$ oranın SBÖP açısından oldukça önemli bir oran olduğu söylenebilir.

Kalaycı ve Baysal (2020) yaptıkları çalışmada SBÖP'de öğrenci öz değerlendirmesinin olmadığı sonucuna ulaşmışlardır. Yapılan bu çalışma sonucunda da benzer bir sonuca ulaşılmıştır. 2019-2020 eğitim-öğretim y1lında okutulan 4-7. sınıf sosyal bilgiler ders kitapları incelendiğinde sadece 7. sınıf sosyal bilgiler ders kitabında yer alan tüm öğrenme alanlarında öğrenci öz değerlendirme formlarına ulaşılmıştır. Aslında öğrenci öz değerlendirme formlarının öğrencilerin öğrenme alanları sonunda kendilerini değerlendirmelerine olanak sağladığı için önemli bir değerlendirme olduğu söylenebilir. 6. sınıf sosyal bilgiler ders kitabının tüm öğrenme alanlarının sonunda "oynayalım-öğrenelim" adı altında çocukların ilgisini çekebilecek kavram öğretimine yer verilmiştir. Bu bağlamda öğrenme alanlarının sonunda öğrenci öz değerlendirmesinin yer alması ve kavram öğretiminin oyunlaştırılarak öğretilmesi öğrencilerin ilgisini çekmesi ve dolayısıyla öğrenmeleri açısından oldukça faydalı olduğu söylenebilir. Bu bağlamda bu çalışmanın bulgularından yola çıkarak aşağıdaki önerilere yer verilmiştir.

1. Ders kitaplarında yer alan öğrenme alanları sonunda öğrenci öz değerlendirmelerine ve kavram öğretimine yönelik oyunlara yer verilebilir. 
2. SBÖP'de yer alan coğrafya kavramlarıyla ilgili kazanımların sayısı artırilabilir.

3. Sosyal bilgiler (4-7. sınıflar) ders kitaplarındaki coğrafya kavramlarına ilişkin öğrenme alanlarında yer alan coğrafya kavramları ile ilgili edebi ürünlere (şiir, hikâye, destan vb.) daha fazla yer verilebilir.

4. Altı ve yedinci sınıf sosyal bilgiler ders kitaplarında bütünlüğ̈n sağlanması için "ünite" kavramı yerine "öğrenme alanı" kavramı kullanılabilir.

5. SBÖP'de coğrafya kavramları ile ilgili becerilere daha fazla yer verilebilir.

\section{KAYNAKLAR}

Akpunar, Burhan (2010), "Yapılandırmacı Yaklaşımda Öğretmenin, Öğrencinin ve Velinin Rolü”, Eğitime Bakış Dergisi, Cilt. 6, Sayı: 16, ss. $16-20$.

Ambarl, Aytaç (2010), Türkiye'de Cumhuriyetten Günümüze Sosyal Bilgiler Programları (Değişiklikler, Düzenlemeler, Güncellemeler), Yayımlanmamış Yüksek Lisans Tezi. Selçuk Üniversitesi Eğitim Bilimleri Enstitüsü, Konya.

Aydın, Mesut (2016), Alternatif Yaklaşımlarla Sosyal Bilgiler Eğitimi (1.baskı), R.Sever, M.Aydın ve E.Koçoğlu (Yay. haz.), Tarihsel Empatiyle Sosyal Bilgiler Öğretimi içinde (ss. 15-27), Pegem Akademi Yayıncılık, Ankara.

Aykaç, Necdet (2007), "İlkögretim Sosyal Bilgiler Dersi Egitim-Ögretim Programına Yönelik Öğretmen Görüssleri”, Elektronik Sosyal Bilimler Dergisi, Cilt 6, Say1: 22, ss. 46-73.

Bebe, Halil İbrahim ve Ünlü, Mehmet (2012), “illköğretim 6. Sınıf Sosyal Bilgiler Dersinin Coğrafya İçeriği Açısından Yeterliliği”, Marmara Coğrafya Dergisi, Say1: 26, ss. 260-286.

Can, Büşra (2019), 2005 ve 2018 Sosyal Bilgiler Dersi Öğretim Programlarının İncelenmesi, Yayımlanmamış yüksek lisans tezi, Balıkesir Üniversitesi Sosyal Bilimler Enstitüsü, Balıkesir.

Çakmak, Zafer - Kaçar, Turan - Arıkan, İrfan (2017), "Sosyal Bilgiler Öğretmenlerinin Ortaokul Sosyal Bilgiler Dersi Taslak Öğretim Programına İlişkin Görüşleri”, Akademik Sosyal Araştırmalar Dergisi, Cilt 5, Say1: 54, ss. 576-597. 
Çakmak, Zafer - Arıkan, İrfan ve Kaçar, Turan (2019, Şubat), Sosyal Bilgiler Öğretim Programları Üzerine Yapılan Çalışmaların Çeşitli Değişkenler Açısından İncelenmesi: 2005-2018 Yılları. 4. Uluslararası El Ruha Sosyal Bilimler Kongresi, Şanlıurfa, Türkiye.

Çelikkaya, Taner ve Kürümlüoğlu, Mutlu (2018), "Yenilenen Sosyal Bilgiler Dersi Öğretim Programına Yönelik Öğretmen Görüşleri”, Uluslararası Türk Eğitim Bilimleri Dergisi, Cilt. 6, Sayı: 11, ss. 104-120.

Çoban, Okan ve Akşit, İbrahim (2018), “2005 ve 2017 Sosyal Bilgiler Öğretim Programlarının Öğrenme Alanı, Kazanım, Kavram, Değer ve Beceri Boyutları Açısından Karşılaştırılmasıı”, Journal of History Culture and Art Research, Cilt. 7, Say1: 1, ss. 479-505. doi: http://dx.doi.org/10.7596/taksad.v7i1.1395

Demirel, Özcan (2013), Eğitimde Program Geliştirme Kuramdan Uygulamaya (20. Baskı), Pegem Akademi Yayınları, Ankara.

Dinç, Erkan ve Doğan, Yasin (2010), “ïlköğretim İkinci Kademe Sosyal Bilgiler Öğretim Programı Ve Uygulanması Hakkında Öğretmen Görüsşleri”, Sosyal Bilgiler Eğitimi Araştırmaları Dergisi, Cilt. 1, sayı: 1, ss. 17-49.

Dursun, Ayşe (2019), 2018 Sosyal Bilgiler Öğretim Programı'na İlişkin Öğretmen ve Akademisyenlerin Görüş ve Değerlendirmeleri Yayımlanmamış yüksek lisans tezi, Marmara Üniversitesi Eğitim Bilimleri Enstitüsü, İstanbul.

Gümüş, Nevzat - Akyol, Canan - Avc1, Görkem - Dikicigil, Özdemir (2019), "Sosyal Bilgiler Dersi Öğretim Programındaki Becerilerin 7. Sinıf Sosyal Bilgiler Ders Kitabında Yer Alan Etkinlikler Kapsamında İncelenmesi”, The Journal of Academic Social Science Studies, Say1: 77, ss. 219-229.

Güven, Sevim (2011), Sosyal Bilgiler Dersinde Vatandaşlık Eğitimi ve Vatandaşlık Eğitiminde Modeller, R. Turan, A.M. Sünbül ve H. Akdağ (Yay. haz.). Sosyal Bilgiler Öğretiminde Yeni Yaklaşımlar II (I. baskı) içinde (s. 36-56). Ankara, Pegem Akademi Yayınları.

Kalayc1, Nurdan ve Baysal, Sefa Burak (2020), "Sosyal Bilgiler Öğretim Programlarının Karşılaştırmalı Analizi (2005-2017-2018)”, Afyon Kocatepe Üniversitesi Sosyal Bilimler Dergisi, Cilt. 22, Sayı: 1, ss.106129. 
Karasu Avc1, Emine ve Faiz, Melike (2018), “4. ve 5. Sınıf Sosyal Bilgiler Ders Kitapları 'Etkin Vatandaşlık' Öğrenme Alanında Yer Alan Becerilerin ve Değerlerin İncelenmesi”, Uluslararası Sosyal Bilgilerde Yeni Yaklaşımlar Dergisi, Cilt. 2, Sayı: 1, ss. 1-21.

Karatekin, Karatekin ve Sönmez, Ömer Faruk (2016), Sosyal Bilgiler Öğretiminde Neden Coğrafya?, D.Dilek (Yay. haz.) Sosyal Bilgiler Eğitimi (1.bask1) (s. 151-178) içinde, Pegem Akademi, Ankara.

Kaya, Mehmet Fatih ve Tomal, Necati (2011), "Sosyal Bilgiler Dersi Öğretim Programı'nın Sürdürülebilir Kalkınma Eğitimi Açısından İncelenmesi”, Eğitim Bilimleri Araştırmaları Dergisi Uluslararası EDergi, Cilt. 1, Say1: 2, ss. 49-65.

Kızılçaoğlu, Alaattin ve Taş, Halil İbrahim (2007), “İlköğretim İkinci Kademede Coğrafya Eğitimi Ve Öğretimi: Öğrenme Alanları ve Kazanım Boyutu”, Marmara Coğrafya Dergisi, Sayı: 16, ss. 93-108.

Koçoğlu, Erol ve Aydın, Mesut (2017), “Alan Uzmanlarına Göre 2017 Sosyal Bilgiler Programının 2005 Programı Çerçevesinde Analizi”, International Journal of Social Science Research, Cilt. 6 Sayı: 1, ss. 6072 .

Milli Eğitim Bakanlığı, Öğretim Programları İzleme ve Değerlendirme Sistemi (2018), http://mufredat.meb.gov.tr/ProgramDetay.aspx?PID=354, (01.05.2020)

Özdemir Özden, Döndü (2016), Güney Afrika Cumhuriyeti C. Öztürk (Yay. haz.), Farklı Ülkelerin Sosyal Bilgiler Öğretim Programı (2. baskı), (ss. 143-172), Pegem Akademi Yayınları, Ankara.

Özdemir, Soner Mehmet (2014), Sosyal Bilgiler Öğretimi Programı ve Değerlendirilmesi M. Safran (Yay. haz.), Sosyal Bilgiler Öğretimi (3. baskı). (ss. 18-48), Pegem Akademi Yayınları, Ankara.

Öztürk, Cemil (2015), Sosyal Bilgiler: Toplumsal Yaşama Disiplinler Arası Bir Yaklaşım C.Öztürk (Yay. haz.), Sosyal Bilgiler Öğretimi Demokratik Vatandaşılı Eğitimi (4.baskı) (ss. 2-28), Pegem Akademi Yayıncılık, Ankara.

Öztürk, Cemil ve Otluoğlu, Rahmi (2003), Sosyal Bilgiler Öğretiminde Edebi Ürünler ve Yazılı Materyaller (2.baskı), Pegem Akademi Yayıncılık, Ankara. 
Sağdıç, Mustafa (2019), “Türkiye'de Sosyal Bilgiler Eğitiminde Disiplinlerarası Öğretim Yaklaşımının Tarihsel Gelişimi”, Journal of History Culture and Art Research, Cilt. 8, Say1: 2, ss. 390-403. doi: http://dx.doi.org/10.7596/taksad.v8i2.2121

Selvi, Habip (2018). Sosyal Bilgiler Dersi 2005 ve 2018 Öğretim Programlarının Karşılaştırılması, Yayımlanmamış yüksek lisans tezi, Kütahya Dumlupınar Üniversitesi Eğitim Bilimleri Enstitüsü, Kütahya.

Sönmez, Veysel (2010), Sosyal Bilgiler Öğretimi, Anı Yayıncılık, Ankara.

Turan, Saim (2019), “2018 Sosyal Bilgiler Öğretim Programının Disiplinlerarası Yapısının İncelenmesi", Journal of Innovative Research in Social Studies, Cilt. 2, Sayı: 2, ss. 166-190.

Ünal, Ayşe Vildan ve Özkaral, Tuğba Cevriye (2019, Haziran), “2018 Sosyal Bilgiler Ders Kitabı İle Ders Kitaplarının Harita Kullanımı Açısından İncelenmesi”, I. İstanbul Uluslararası Coğrafya Kongresi, İstanbul. doi: 10.26650/PB/PS12.2019.002.018

Yeşiltaş, Namık Kemal ve Kaymakcı, Selahattin (2009), “John Dewey’nin Eğitim Anlayışı ve Sosyal Bilgiler Eğitimine Yönelik Bazı Örnek Uygulamaları”, Kars Kafkas Üniversitesi Sosyal Bilimler Enstitüsü Dergisi, Say1: 4, ss. 227-242.

Yeşilyurt, Etem (2011), “Yapılandırmacı Öğrenme Temelli Bir Öğretim Programının Oluşturulmasına İlişsin Öğretmen Adaylarının Görüşlerinin Değerlendirilmesi”, Turkish Studies, Cilt. 6, Sayı: 4, ss. 865-885.

Yıldırım, Ali ve Şimşek, Hasan (2008), Sosyal Bilimlerde Nitel Araştırma Yöntemleri (6. Bask1), Seçkin Yayıncılık, Ankara.

Yıldırım, Ali ve Şimşek, Hasan (2013), Sosyal Bilimlerde Nitel Araştırma Yöntemleri (9. Baskı), Seçkin Yayıncılık, Ankara. 